\title{
IMPLEMENTASI DALAM PENYELESAIAN PERMASALAHAN AHLI WARIS PENGGANTI (STUDI BANDING BERDASARKAN HUKUM WARIS ISLAM DAN HUKUM WARIS PERDATA)
}

\author{
Sarijo ${ }^{*}$, Akhmad Khisni ${ }^{* *}$ \\ * Mahasiswa Program Magister (S2) Kenotariatan Fakultas Hukum UNISSULA, Semarang, e-mail: \\ sarijoshmh123@gmail.com \\ ** Dosen Fakultas Hukum UNISSULA, Semarang
}

\section{ABSTRACT}

The study aims to determine the extent to which the replacement of substituted heirs in the case of a substituted heirs system, the implementation of substituted heirs and parts thereof, and the similarities and differences of substitute heirs under the Law of Inheritance and the Law of Inheritance of the Civil Code.

The research used with approach method that is juridical normative method is legal research done by giving priority to researching library materials and documents. The specification in this research is using analytical descriptive, this method aims to provide an overview that is done by using a qualitative way that consists of: Theory-theory of law, legal doctrines, as well as opinions from legal experts.

The results of this study and discussion: 1) The system of heirs according to Islamic Law is "the amount of property of the deceased in the net, after deducting the payment of the debts of the testator". Whereas in the law of the inheritance of the Civil Code there is no known regulatory difference on the basis of the kind or origin of goods left by the heirs.2) According to the Islamic inheritance law that the lineage entitled to obtain part of the substitute is replaced by a downward straight line, from a straight line upward and from a straight line to the side. Meanwhile, according to the law of the Civil Code inheritance from Hazairin's teaching that the brother of his father, both male and female, is not a barrier to replace his father's position, it is most important that his father had died earlier than the heir (grandfather). 3) The equality of the surrogate heirs in both laws is a person who succeeds the heirs who first passed away from the heirs who should have acquired the inheritance, and the replaced heir is the link between a person who succeeds and heirs. While the difference in terms of replacing the position of his father and: the rights obtained by the successor heirs

Keywords: heirs, surrogate heirs, Mawali, Islamic Inheritance Law, Inheritance Law of the Civil Code.

\section{PENDAHULUAN}

Ahli waris pengganti menurut kewarisan hukum Islam (Mawall) adalah seseorang yang menggantikan kedudukan seorang ahli waris dan memperoleh bagian warisan yang tadinya akan diperoleh orang yang digantikan, sedangkan orang yang di gantikannya telah meninggal dunia. Dengan tujuan untuk mengetahui sejauh mana penggantian kedudukan ahli waris pengganti dalam hal sistem ahli waris pengganti, implementasi kedudukan ahli waris pengganti dan bagiannya, serta persamaan dan perbedaan ahli waris pengganti menurut Hukum Kewarisan Islam dan Hukum Kewarisan Kitab Undang-Undang Hukum Perdata.

Al-Qur'an telah selesai pewahyuannya, demikian
Sunnah Rasulullah telah selesai pula sesudah wafat Rasulullah. Adapun kehidupan ini tidak pernah selesai, selalu berubah dan yang abadi adalah perubahan itu sendiri, atau dengan istilah lain ' $A n$ nushush mutanahiyah wal waqa'iq ghairu

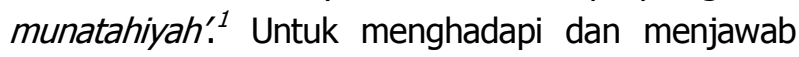
permasalahan tersebut di atas perlu melakukan 'tajdid al-fahmi' (pembaharuan pemahaman) tidak cukup hanya pemahaman tekstual, akan tetapi dibutuhkan pendekatan penggalian 'ruh' (jiwa) suatu ayat dengan metode 'maqashid al-syariah' (tujuan hukum) berupa apa sebenarnya ide atau kehendak

\footnotetext{
${ }^{1}$ A. Khisni, Transformasi Hukum Islam ke dalam Hukum Nasional, Cet. 1 (Yogyakarta: ProgramDoktor Ilmu Hkm Program Pascasarjana Fakultas Hukum UII,2011), hal.ix.
} 
Allah yang diwahyukan dalam ayat al-Qur'an.

Pemikiran adalah 'proses' atau 'cara' berpikir tentang hukum Islam. Perkembangan adalah proses berpikir yang tidak dimulai dari titik 0 (nol), tetapi sudah terdapat modal atau bahan untuk mencapai kesempurnaan. Dari sini terdapat permasalahan mengapa ada campur tangan pemikiran manusia dalam hukum Islam?, kemudian faktor-faktor apa saja sebagai penyebab bagi timbulnya pemikiran dalam hukum Islam. ${ }^{2}$

Berpikir merupakan sunnatullah untuk menjawab permasalahan kehidupan dalam hal ini adalah bidang hukum (Islam) dengan menggunakan akal sehat. Dalam hukum Islam akal (al-ra'yu) merupakan sumber (alat/metode) hukum Islam yang ketiga melalui ijtihad, selain pertamadan utama adlh Al-Qur'an dan yg kedua as-Sunnah. Pengakuan AlQur'an terhadap peranan akal pikiran dalam bidang hukum dapat disimpulkan dari kandungan ayat 59 Surat an-Nisaa'. Perintah untuk mentaati ulil - amri dalam ayat tersebut tidak lain pengertiannya adalah mentaati hasil ijtihad mereka yang dilakukan dengan sungguh-sungguh. Dengan demikian, menggunakan akal pikiran dalam masalah keagamaan (hukum Islam) merupakan tuntutan keagamaan. ${ }^{3}$ Hukum Islam merupakan hukum Allah SWT, dan sebagai hukum Allah menuntut kepatuhan dari umat Islam untuk melaksanakannya sebagai kelanjutan dari keimanannya terhadap Allah SWT. Keimanan akan wujud Allah menuntut kepercayaan akan segala sifat, kodrat, dan idarat Allah. Aturan Allah tentang tingkahlaku manusia itu sendiri merupakan satu bentuk dari idarat Allah dan karena itu, maka kepatuhan menjalankan aturan Allah merupakan perwujudan dari iman kepada Allah. ${ }^{4}$

Sistem hukum di Indonesia sangatlah beraneka ragam, ditambah dengan belum adanya unifikasi hukum kewarisan diIndonesia yang merupakan bagian dari hukum perdata Indonesia, sehingga sampai saat ini kita masih memakai tiga sistem hukum kewarisan yang sudah ada sejak dahulunya, yaitu :

\footnotetext{
${ }^{2}$ A. Khisni, Aliran-aliran Pemikiran dalam Hukum Islam, Cet. 1 (Semarang: Unissula Press,2013), hal. 5.

${ }^{3}$ Ibid., hal. 9.

${ }^{4}$ Amir Syarifuddin, Hukum Kewarisan Islam, Edisi

Kedua. ( Jakarta: Kencana Prenada Media Group, 2014). HIm. 2.
}

1. Sistem Hukum Kewarisan Adat

Sistem hukum kewarisan adat yang beraneka ragam, hal ini dipengaruhi oleh bentuk masyarakat diberbagai daerah lingkungan hukum adat dan sifat kekerabatan berdasarkan keturunan. Setiap sistem keturunan memiliki kekhususan dalam hukum warisnya yang satu dengan yang lainnya saling berbeda.

2. Sistem Hukum Kewarisan Islam.

Hukum kewarisan yang lazim disebut dengan Hukum Faraid merupakan bagian dari keseluruhan hukum Islam yang khusus mengatur dan membahas tentang proses peralihan harta peninggalan dan hak-hak serta kewajiban seseorang yang telah meninggal dunia kepada yang masih hidup.

3. Sistem Hukum Kewarisan Perdata Barat Sistem kewarisan yang tertuang dalam Burgerlijk Wetboek (BW) atau (KUHPerdata) yang menganut sistem individual, dimana setelah pewaris meninggal dunia maka harta peninggalan pewaris haruslah segera dilakukan pembagian kepada ahli waris.

Hukum merupakan tatanan kehidupan yang bertujuan menciptakan keadilan dan ketertiban masyarakat. Oleh karena itu setiap hukum yang dibuat senantiasa harus merefleksikan khendak masyarakat agar dapat memenuhi rasa keadilan. Hukum yang dibuat pada masa lalu seringkali dirasa tidak sesuai dgn rasa keadilan masyarakat saat ini disebabkan berubahnya kondisi sosial masyarakat sehingga perlu dilakukan perubahan.

Pada dasarnya pewaris sebagai pemilik harta mempunyai hak mutlak, untuk mengatur apa saja yang dikhendakinya, akan tetapi kebebasan tersebut dapat membawa kerugian kepada ahli waris, oleh karenanya pembentuk Undang-undang menetapkan kelompok ahli waris yang mempunyai hak mutlak atas harta peninggalan dengan diberikannya legitime portie yaitu bagian dari harta kekayaan yang harus diberikan kepad ahli waris ab intestate. Pengalihan harta waris berdasarkan testamen tergantung kepada ada tidaknya harta yang masih tersedia setelah bagian legitime portie para ahli waris sudah terpenuhi dahulu. ${ }^{5}$

\footnotetext{
${ }^{5}$ Elisabeth Nurhaini Butarbutar, Hukum Harta Kekayaan (Bandung: Refika Aditama, 2012). HIm. 21-22.
} 
Sehingga untuk memperjelas suatu penelitian lebih lanjut terbatas kepada perbandingan antara Hukum Kewarisan Islam dan Hukum Kewarisan KUHPerdata mengenai ahli waris pengganti kedua perbedaan sistem hukum tersebut, maka untuk mencari titik temu ahli waris pengganti dari Hukum Kewarisan Islam dan Hukum Kewarisan KUHPerdata.

Berdasarkan uraian latar belakang tersebut, permasalahan dalam penelitian ini adalah sebagai berikut : Bagaimana sistem ahli waris pengganti menurut Hukum Kewarisan Islam dan Hukum Kewarisan kitab Undang-Undang Hukum Perdata? Bagaimana implementasi kedudukan ahli waris pengganti dan bagiannya menurut Hukum Kewarisan Islam dan Hukum kewarisan kitab Undang-Undang Hukum Perdata? Bagaimana persamaan dan perbedaan ahli waris pengganti menurut Hukum Kewarisan Islam dan Hukum Kewarisan Kitab Undang-Undang Hukum Perdata?

\section{METODOLOGI PENELITIAN}

Metode pendekatan yang digunakan dalam penelitian ini adalah metode yuridis normatif, yaitu penelitian hukum yang dilakukan dengan mengutamakan meneliti bahan pustaka dan dokumen yang disebut data sekunder, berupa bahan-bahan hukum primer, sekunder, dan tersier.

Metode penelitian yang digunakan dalam penelitian ini adalah penelitian untuk menemukan hukum in concreto, yaitu penelitian yang bertujuan untuk menemukan apakah hukum yang sesuai untuk diterapkan guna menyelesaikan suatu perkara tertentu. ${ }^{6}$ Spesifikasi penelitian yang akan digunakan adalah deskriptif analitis, metode ini bertujuan untuk memberikan gambaran yang dilakukan dengan menggunakan cara kualitatif. Metode Pengumpulan Data, untuk Data Sekunder diperoleh melalui studi pustaka atau literatur, Data sekunder tersebut meliputi:

a. Bahan Hukum Primer, yang merupakan bahan hukum yang mengikat berupa peraturan perundang-undangan yang antara lain dari:

1) Al-Qur'an dan Hadist.

2) KUHPerdata (Burgelijk Wetboek);

3) Kompilasi Hukum Islam Pasal 185, 171, 172,

\footnotetext{
${ }^{6}$ Ibid, hal 26.
}

\section{3}

b. Bahan Hukum Sekunder yang merupakan bahanbahan hukum yang memberikan penjelasan mengenai bahan hukum primer,berupa:

1) Buku-buku literatur;

2) Majalah-majalah;

3) Artikel-artikel media;

4) Dan berbagai tulisan lainnya.

c. Bahan Hukum Tersier yang merupakan bahanbahan hukum yang memberikan petunjuk maupun penjelasan terhadap bahan hukum primer dan sekunder.

Metode yang digunakan dalam menganalisis dan mengolah data-data yang terkumpul adalah analisis kualitatif. Maksud dari penggunaan metode tersebut adalah memberikan gambaran terhadap permasalahan berdasarkan pada pendekatan yuridis normatif. ${ }^{7}$

\section{HASIL PENELITIAN DAN PEMBAHASAN}

\section{Sistem Ahli Waris Pengganti Menurut Hukum Kewarisan Islam dan KUHPerdata.}

Wujud warisan atau harta peninggalan menurut Hukum Islam sangat berbeda dengan wujud warisan menurut waris Barat sebagaimana diatur dalam BW maupun menurut hukum waris adat. Warisan atau harta peninggalan menurut Hukum Islam yaitu "sejumlah harta benda serta segala hak dari yang meninggal dunia dalam keadaan bersih". Artinya, harta peninggalan yang diwarisi oleh para ahli waris adalah sejumlah harta benda serta segala hak, "setelah dikurangi dengan pembayaran hutanghutang pewaris dan pembayaran-pembayaran lain yang diakibatkan oleh wafatnya sipninggal waris".

Hukum kewarisan menurut hukum Islam sebagai salah satu bagian dari Hukum kekeluargaan dan dalam pelaksanaan pembagian harta warisan tidak terjadi kesalahan dan dapat dilaksanakan dengan seadil-adilnya. Karna dalam hukum kewarisan Islam bagi umat Islam akan dapat menentukan hal-hal yang berkenan dengan harta warisan setelah ditinggal oleh pewaris dan di

7 Ade Saptomo, Pokok-Pokok Metodologi Penelitian Hukum, (Surabaya, Unesa University Press, 2007), hal 30.

${ }^{8}$ Wirjono Prodjodikoro, Op.cit., hlm. 17. 
sampaikan kepada ahli waris yang berhak untuk menerimanya, sehingga dengan demikian seseorang dapat terhindar dari dosa dan tidak memakan harta yang bukan haknya, karena dikenaikannys hukum Islam mengenai kewarisan. ${ }^{9}$

Dalam Buku II pada BAB I ketentuan pasal 171 Kompilasi Hukum Islam antara lain disebutkan Pewaris adalah orang yang pada saat meninggalnya atau yang dinyatakan meninggal berdasarkan putusan Pengadilan beragama Islam, meninggalkan ahli waris dan harta peninggalan. Ahli waris adalah orang yang pada saat meninggal dunia mempunyai hubungan darah atau hubungan perkawinan dgn pewaris, beragama Islam dan tidak terhalang karena hukum untuk menjadi ahli waris. ${ }^{10}$

Ahli waris pengganti menurut bahasa Arab adalah Mawali, artinya orang yang menggantikan seseorang dan memperoleh bagian warisan yang tadinya akan diperoleh orang yang di gantikan, sedangkan orang yang digantikannya adalah orang yang seharusnya menerima warisan kalau dia masih hidup, tetapi dalam kasus bersangkutan dia telah meninggal dahulu dari pewaris dan orang yang digantikan hendaklah merupakan penghubung antara dia yang menggantikan dengan pewaris yang meninggalkan harta peninggalan. Sedangkan mereka yang menjadi mawali adalah keturunan anak pewaris, keturunan saudara pewaris atau keturunan orang yang mengadakan semacam perjanjian mewaris dengan pewaris. ${ }^{11}$

Berbagai upaya positif telah dilakukan oleh Badan Pembinaan Hukum Nasional menuju pembentukan Hukum Nasional diberbagai bidang di Indonesia,termasuk diantaranya Hukum Kewarisan. Berkenaan dengan reformasi Hukum Kewarisan Islam yang berlaku diIndonesia hingga saat ini tampaknya belum memuaskan. Bahkan berbagai pihak terutama kalangan penegak hukum dilingkungan Mahkamah Agung dan Departemen Agama RI yang berada didalam panitia penyusunan kompilasi hukum Islam berhasil memaksakan

\footnotetext{
9 Salman otjc. Hukum Waris Islam. Bandung: Rafika Aditama.

${ }^{10}$ Departemen Agama R.I. Direktorat Jendral Pembinaan Kelembagaan Agama Islam Tahun 1997/1998. Kompilasi Hukum Islam di Indonesia. HIm. 77-78.

11 Ash Shabuni Muhammad Ali, Pembagian Waris Menurut Islam. Jakarta: Gema Insani, 1995., HIm. 25.
}

masuknya hasil penalaran Hazairin dalam kompilasi hukum Islam yang telah djadikan satu dengan inpres dan dalam konsideran inpres tersebut bahwa kompilasi hukum Islam merupakan hasil kesepakatan dari seluruh ahli ulama dan telah pula dikukuhkan didalam yurisprodensi Peradilan Agama dan Mahkamah Agung.

Adapun hal-hal yang paling penting yang mengatur hukum kewarisan adalah dicantumkannya klausul materi hukum mengenai keberadaankeberadaan ahli waris pengganti yang dianggap telah melembaga dan diopinikan oleh masyarakat selama sembilan belas tahun.

\section{Implementasi Kedudukan Ahli Waris Pengganti Dan Bagiannya Menurut Hukum Kewarisan Islam Dan KUHPerdata}

Kedudukan ahli waris pengganti timbul akibat adanya pembatasan bagian sebagai mana diatur dalam Pasal 185 Kompilasi Hukum Islam (KHI) diIndonesia pada ayat 2 yang menyatakan bagian ahli waris pengganti tidak boleh melebihi dari bagian ahli waris yang sederajat yang diganti, dengan demikian pada Pasal tersebut menggunakan kalimat "yang sederajat" tidak mencukupkan dengan kalimat bagian ahli waris pengganti tidak boleh melebihi bagian ahli waris yang diganti dengan menghilangkan kalimat yang sederajat.

Ada beberapa pendapat kedudukan ahli waris pengganti yang menggantikan kedudukan orang tuanya apabila pewaris tidak meninggalkan anak lakilaki yang lain yang masih hidup. Namun demikian apabila ada wasiat wajibah maka kepada cucu dari anak laki-laki yang terhijab tidak mendapatkan warisan dari kakeknya.

Menurut hukum kewarisan Islam bahwa garis keturunan yang berhak memperoleh bagian dari yang menggantikan kedudukan digantikan oleh garis lurus kebawah seterusnya, dari garis lurus keatas serta dari garis menyamping. Sedangkan Menurut hukum kewarisan KUHPerdata dari ajarannya Hazairin bahwa saudara dari ayahnya baik laki-laki ataupun perempuan bukan menjadi penghalang untuk seorang anak yang menggantikan kedudukan ayahnya dalam memperoleh harta warisan kakeknya, yang terpenting bahwa ayahnya tersebut telah meninggal lebih dulu dari sipewaris (kakeknya). 


\section{Persamaan dan Perbedaan Ahli Waris Pengganti Menurut Hukum Kewarisan Islam Dan Menurut Hukum Kewarisan KUHPerdata}

a. Persamaan Ahli Waris Pengganti Menurut Hukum Kewarisan Islam Dan Hukum Kewarisan KUHPerdata

Mengenai persamaan kedua hukum tersebut ahli waris pengganti dalam pengertiannya pada dasarnya sama, yaitu seseorang yang menggantikan kedudukan ahli waris yang lebih dulu meninggal dari pewaris yang seharusnya memperoleh harta warisan itu, dan ahli waris yang digantikan merupakan penghubung antara seseorang yang menggantikan dengan pewaris. Begitu pula pada saat pewaris meninggal, seperti anak yang menggantikan kedudukan ayahnya.

\section{b. Perbedaan Ahli Waris Pengganti Menurut Hukum Kewarisan Islam Dan Hukum Kewaisan KUHPerdata}

Perbedaan ahli waris pengganti menurut kedua hukum tersebut sebagai berikut :

1) Menurut hukum kewarisan Islam atas dasar pendapat As-Sunnah, bahwa anak yang menggantikan kedudukan ayahnya adalah anak laki-laki dan anak perempuan dari garis keturunan laki-laki yang ayahnya sudah meninggal terlebih dahulu dari pewaris. Sedangkan anak laki-laki dan anak perempuan dari garis keturunan perempuan tidak berhak sama sekali menggantikan kedudukan ibunya untuk memeperoleh harta dari pewaris.

Menurut hukum kewarisan KUHPerdata yang segaris lurus dengan ajaran Hazairin bahwa anak yang menggantikan kedudukan ayahnya itu boleh dari garis keturunan laki-laki maupun dari garis keturunan perempuan, yang terpenting bahwa orang yang digantikan kedudukannya itu sudah lebih dulu meninggal dari pewaris dan dia (orang yeng menggantikan) merupakan penghubung antara anaknya (yang menggantikan kedudukan ayahnya) dengan si pewaris.

2) Menurut hukum kewarisan Islam berdasarkan pendapat As-Sunnah bahwa cucu dari anak lakilaki baru dapat menggantikan kedudukan orang tuanya apabila pewaris tidak meninggalkan anak laki-laki yang lain yang masih hidup. Apabila syarat tersebut tidak terpenuhi maka cucu tersebut terhijab oleh saudara ayahnya itu dan tidak akan memperoleh bagian dari harta warisan kekeknya. Namun demikian ada wasiat wajibah yang memberi peluang kepada cucu dari anak laki-laki yang terhijab untuk mendapatkan warisan dari kakeknya.

Menurut hukum kewarisan KUHPerdata dan pendapat Hazairin bahwa saudara dari ayahnya baik laki-laki maupun perempuan bukan menjadi penghalang untuk seseorang anak yang menggantikan kedudukan ayahnya dalam memperoleh harta warisan kakeknya yang terpenting bahwa ayah tersebut telah meninggal lebih dahulu dari sipewaris (kakeknya).

3) Menurut hukum kewarisan Islam pendapat AsSunnah dan Hazairin, hak yang diperoleh ahli waris pengganti itu belum tentu sama dengan hak orang yang digantikan, dan juga tidak boleh melebihi dari bagian ahli waris yang sederajat dengan yang diganti, tetapi bisa kurang dari bagian ahli waris yang digantikan.

Menurut hukum kewarisan KUHPerdata (BW), bagian yang akan diperoleh oleh ahli waris yang menggantikan kedudukan ayahnya persis sama dengan bagian yang seharusnya diperoleh ayahnya sandainya ayahnya masih hidup dari pewaris.

4) Menurut hukum kewarisan Islam bahwa garis keturunan yang berhak memperoleh bagian dari menggantikan kedudukan orang yang digantikan adalah dari garis lurus kebawah dan seterusnya, dari garis lurus keatas serta garis lurus kesamping.

Menurut hukum kearisan KUHPerdata yang berhak menggantikan hanya dari keturunan garis lurus kebawah dan seterusnya, serta garis menyamping.

\section{PENUTUP}

\section{Kesimpulan}

Dari hal-hal yang telah diuraikan tersebut diatas, Penulis menyimpulkan sebagai berikut:

1. Sistim ahli waris pengganti menurut Hukum Kewarisan Islam dan Hukum Kewarisan KUHPerdata dapat diterapkan apabila seseorang ahli waris pengganti terlebih dahulu meninggal maka ahli waris berikutnya berhak menggantikan 
kedudukan dari sang ayah untuk mendapatkan harta warisan dari kakeknya.

2. Implementasi kedudukan ahli waris pengganti dan bagiannya menurut Hukum Kewarisan Islam Dan Hukum Kewarisan KUHPerdata adalah kedudukan ahli waris pengganti bagiannya tidak boleh melebihi bagian ahli waris yang sederajat dengan yang diganti, oleh karenanya pada Pasal 185 ayat 2 Kompilasi Hukum Islam kedudukan dan hak-hak tanpa batas dan tanpa diskriminasi antara laki-laki dan perempuan menjadi ahli waris pengganti menempati kedudukan orang tuanya secara mutlak.

3. Persamaan dan perbedaan ahli waris pengganti menurut Hukum Kewarisan Islam dan Hukum Kewarisan KUHPerdata adalah sebagai berikut :

- Persamaan :

Pada prinsipnya ahli waris pengganti terhadap kedua hukum tersebut adalah sama, yaitu apabila seseorang yang menggantikan kedudukan ahli waris yang lebih dahulu meninggal dari pewaris yang seharusnya memperoleh harta warisan tersebut, sedangkan ahli waris yang digantikan merupakan suatu penghubung antara seorang yang menggantikan dengan pewaris serta ahli waris pengganti pada saat pewaris meninggal dunia.

Perbedaan :

a. Menurut kewarisan Hukum Islam adalah merupakan suatu bagian yang diterima ahli waris pengganti tertentu sama dengan bagian orang yang digantikan daalm pembagian harta warisan ahli waris pengganti laki-laki menerima lebih banyak daripada perempuan.

Menurut Hukum Kewarisan KUHPerdata bagian yang akan diterima oleh ahli waris pengganti porsinya sama dengan bagian yang seharusnya diperoleh sama ahli waris yang digantikannya, bagian ahli waris pengganti laki-laki sama dengan bagian ahli waris pengganti perempuan.

b. Menurut Hukum Kewarisan Islam mengenai penggantian ahli waris dalam garis lurus keatas, garis lurus kebawah dan garis lurus menyamping berdasarkan ketentuan kewarisan KUHPerdata hanya sebagai penggantian dalam garis lurus kebawah dan garis lurus menyamping, sehingga dengan demikian dengan adanya beberapa perbedaan pendapat ahli waris pengganti dalam kompilasi Hukum Islam mengakomodir tujuan tercapainya rasa keadilan bagi ahli pengganti dengan tidak merugikan ahli waris pengganti lainnya, oleh karena itu secara umum sistem ahli waris pengganti tidak sama dengan KUHPerdata.

\section{Saran}

1. Ahli waris pengganti baik menurut Kewarisan Hukum Islam maupun menurut Hukum Kewarisan KUHPerdata sebaiknya mulai diterapkan dilembaga peradilan baik dilingkungan Pengadilan Agama maupun Pengadilan Negeri.

2. Ahli waris pengganti di masa-masa mendatang perlu dilakukan suatu penelitian terhadap Kewarisan Hukum Nasional yang berkembang dalam rangka mewujudkan unifikasi hukum.

\section{DAFTAR \\ PUSTAKA}

A. Khisni, Transformasi Hukum Islam ke dalam Hukum Nasional, Cet. 1 (Yogyakarta: Program Doktor Ilmu $\mathrm{Hkm}$ Program Pascasarjana Fakultas Hukum UII,2011)

A. Khisni, Aliran-aliran Pemikiran dalam Hukum Islam, Cet. 1 (Semarang: Unissula Press,2013).

Amir Syarifuddin, Hukum Kewarisan Islam, Edisi Kedua. ( Jakarta: Kencana Prenada Media Group, 2014)

Elisabeth Nurhaini Butarbutar, Hukum Harta Kekayaan (Bandung: Refika Aditama, 2012)

Ade Saptomo, Pokok-Pokok Metodologi Penelitian Hukum, (Surabaya, Unesa University Press, 2007)

Wirjono Prodjodikoro,

Salman otjc. Hukum Waris Islam. Bandung: Rafika Aditama.

Departemen Agama R.I. Direktorat Jendral Pembinaan Kelembagaan Agama Islam Tahun 1997/1998. Kompilasi Hukum Islam di Indonesia.

Ash Shabuni Muhammad Ali, Pembagian Waris Menurut Islam. Jakarta: Gema Insani, 1995 